\title{
Perbedaan Mekanisme Corporate Gover- nance dan Praktik Manajemen Laba: Studi Komparasi Indeks Syari’ah dan Indeks Konvensional di Bursa Efek Indonesia
}

\author{
Rina Trisnawati \\ Universitas Surakarta \\ rinatrisnawati@yahoo.com
}

Earning management (EM) exists as an impact of accrual basis. Based on Agency Theory, earning management problems can be reduced by self-control of corporate governance (CG) mechanism. The purpose this study is to analyze the difference of the CG mechanism and EM between those in accordance with syari'ah index (JII) and conventional index (LQ-45). Samples consist of 89 and 39 companies listed in Bursa Efek Jakarta (BEI) from 2004 to 2007. The result indicates that the EM practice on the conventional index (0.4027) is higher than syari'ah index (0.2337). The regression analysis shows that the board of commissioner size has positive impact on the EM significantly in main model and conventional index model, but not in shari'ah model. The managerial ownership has negative impact on the EM significantly in conventional index model, but not in syari'ah model.

Keywords: earning management, corporate governance, impact, conventional index, syari'ah index.

\section{Pendahuluan}

$\mathrm{M}$ anajemen laba (earnings mangement) merupakan fenomena yang sukar untuk dihindari karena fenomena ini merupakan dampak dari penggunaan dasar akrual dalam penyusunan laporan keuangan. Dalam praktek, sangat wajar apabila para manajer memilih kebijakan-kebijakan tersebut untuk memaksimalkan utilitinya dan nilai pasar perusahaan (Scott, 2006)

Teori agensi memberikan pandangan bahwa masalah earnings management dapat diminimumkan dengan pengawasan sendiri melalui Corporate Governance. Praktek earnings management oleh manajemen dapat diminimumkan melalui mekanisme monitoring untuk menyelaraskan (alignment) perbedaan kepentingan pemilik dan manajemen antara lain dengan (1) memperbesar kepemilikan saham perusahaan oleh manajemen (manajerial ownership) (Jensen dan Meckling, 1976); (2) kepemilikan saham oleh institusional karena mereka dianggap sebagai sophisticated investor dengan jumlah kepemilikan yang cukup signifikan dapat memonitor manajemen yang berdampak mengurangi motivasi manajer untuk melakukan earnings management (Pratana dan Machfoedz, 2003); (3) proporsi dewan 
UNISIA, Vol. XXXII No. 72 Desember 2009

komisaris independen yang membatasi pihak mana-jemen untuk melakukan manajemen laba (Peasnell, Pope dan Young, 1998), (4) ukuran dewan komisaris, dimana jumlah komisaris yang lebih sedikit lebih mampu mengurangi indikasi manajemen laba (Midiastuty dan Machfoedz, 2003) dan (5) keberadaan komite audit yang dapat mengurangi aktivitas earnings management yang selanjutnya akan mempengaruhi kualitas pelaporan keuangan yang salah satunya adalah kualitas laba (Wilopo, 2004).

Praktek corporate governance memiliki hubungan dengan earnings management (Watfield et al. (1995), Gabrielsen et al. (1997), Wedari (2004), Midiastuty dan Machfoedz (2003). Watts (2003) menyatakan bahwa salah satu cara yang digunakan untuk memonitor masalah kontrak dan membatasi perilaku opportunistic manajemen adalah good corporate governance. Jensen (1993) menjelaskan, bahwa melalui penerapan good corporate governance, diharapkan dapat mengurangi dorongan untuk melakukan tindakan manipulasi oleh manajer. Sehingga kinerja yang dilaporkan merefleksikan keadaan ekonomi yang sebenarnya dari perusahaan yang bersangkutan.

Penelitian sebelumnya, Midiastuty dan Machfoedz (2003); Veronica dan Bachtiar (2004); Wedari (2004); Boediono (2005); Kusumawati (2005); Veronica dan Utama (2005); Rahmawati, Suparno dan Qomariyah (2006); Nasution dan Setiawan (2007); Ujiyantho, Arief dan Pramuka (2007); dan Herawaty (2008) memfokuskan pada indeks konvensional (pasar modal konvensional), belum ditemukan penelitian yang mencoba untuk meneliti praktik manajemen laba pada indeks syari'ah (pasar modal syari'ah) dan mengkomparasikan dengan indeks konvensional.
Pasar modal syariah adalah pasar modal yang menggunakan prinsip, prosedur, asumsi, instrumentasi, dan aplikasi bersumber dari nilai epistemologi Islam. Saham-saham di JII di satu sisi merupakan saham yang diperdagangkan sebagaimana saham biasa, tetapi di lain pihak saham tersebut merupakan "ethical investment" karena telah memenuhi beberapa kriteria ekonomi Islam. Ethical investment diartikan telah memenuhi beberapa kriteria baik prinsip ekonomi Islam maupun kriteria saham biasa seperti syarat transaksi. Ethical investment dapat juga dihubungkan dengan teori corporate governance, karena perusahaan-perusahaan yang listing merupakan perusahaan dengan corporate governance yang lebih baik dibanding lainnya (Hanafi, 2007).

Berkaitan dengan diluncurkannya indeks syari'ah di pasar modal Indonesia, sangat menarik apabila dilakukan kajian mengenai praktik earnings management. Hal ini didasari karena sampai saat ini manajemen laba merupakan area yang kontroversial dalam akuntansi keuangan. Praktek manajemen laba dapat dipandang dari dua perspektif yang berbeda, yaitu sebagai tindakan yang salah (negatif) dan tindakan yang seharusnya dilakukan manajemen (positif). Healy dan Wahlen (1998) menganggap manajemen laba sebagai tindakan yang menyesatkan dan menipu pemegang saham. Hal ini disebabkan manajemen memiliki informasi asimetrik mengenai kondisi perusahaan. Widarto (2004) menyatakan, bahwa manajemen laba dianggap tidak etis, bahkan merupakan bentuk dari manipulasi informasi sehingga menyesatkan. Ketika perusahaan melakukan praktik manajemen laba, gambaran laba tidak lagi dapat mewakili kinerja perusahaan secara fair, sehingga akan mengurangi reliabilitas dari laba itu sendiri. Dengan 
Perbedaan Mekanisme Corporate Governance dan Praktik...; Rina Trisnawati

demikian informasi laba menjadi kurang relevan (Whelan dan McNamara, 2004). Tindakan manajer melakukan earnings management dapat berakibat buruk karena bisa menyesatkan pemakai informasi laporan keuangan dan dapat dikategorikan sebagai suatu tindakan penipuan yang tidak etis, siapapun yang menggunakan laporan keuangan yang mengandung unsur earnings management rawan terhadap misinterpretasi, manipulasi ataupun penipuan yang disengaja (Burns dan Merchant, 1990).

Penelitian ini merupakan kelanjutan dari penelitian sebelumnya yang dilakukan oleh Shah, Butt dan Hasan (2009) yang meneliti pengaruh Corporate Governance pada Earnings Management pada Bursa Efek Pakistan. Penelitian ini bertujuan untuk mengetahui bagaimana perbedaan praktik manajemen laba antara perusahaan yang terdaftar dalam indeks syari'ah (diproksikan dengan perusahaan yang terdaftar dalam JII) dan indeks konvensional (diproksikan dengan perusahaan yang terdaftar dalam indeks $L Q$ 45) di Bursa Efek Indonesia, dimana beberapa penelitian di Indonesia sebelumnya belum mengkaji mengenai perbedaan praktik manajemen laba pada kedua indeks tersebut. Periode tahun yang digunakan dalam penelitian ini adalah tahun 2004 2007, dengan dasar bahwa secara formal peluncuran pasar modal dengan prinsipprinsip syari'ah Islam dilakukan pada tanggal 14 Maret 2003 dengan ditandatanganinya nota kesepahaman antara Bapepam dengan Dewan Syariah Nasional - Majelis Ulama Indonesia (DSN-MUI).

Berdasarkan isu penelitian di atas, maka dapat dirumuskan permasalahan sebagai berikut:

1) Apakah praktik manajemen laba yang diproksi dengan discretionary accrual perusahaan yang terdaftar dalam indeks syari'ah lebih rendah dibandingkan dengan indeks konvensional ?

2) Apakah mekanisme corporate governance, dalam hal ini kepemilikan institusional, kepemilikan manajerial, proporsi dewan komisaris independen, ukuran dewan komisaris serta keberadaan komite audit berpengaruh terhadap praktik manajemen laba pada perusahaan yang terdaftar dalam indeks syari'ah dan indeks konvensional?

\section{Kajian Pustaka}

\section{Mekanisme Corporate Gover- nance}

OECD (2004) dan FCGI (2003) mendefinisikan corporate governance sebagai seperangkat peraturan yang menetapkan hubungan antara pemegang saham, pengurus, pihak kreditur, pemerintah, karyawan serta peran pemegang kepen-tingan intern dan ekstern lainnya sehu-bungan dengan hak-hak dan kewajiban mereka..

Hubungan praktek Corporate Governance memiliki hubungan yang signifikan terhadap Earnings Management, lihat Watfield et al.(1995), Gabrielsen et al (1997), Wedari (2004), Midiastuty dan Machfoedz (2003). Hasil penelitian Nasution dan Setiawan (2007) dengan menggunakan sampel perusahaan perbankan yang terdaftar dalam Bursa Efek Jakarta selama periode 2000-2004, menyimpulkan bahwa mekanisme corporate governance telah efektif mengurangi manajemen laba perusahaan perbankan.

Di Indonesia, penelitian mengenai kinerja JII telah dilakukan oleh Hanafi (2007), melalui pendekatan cost of capital terhadap saham JII yang dibandingkan dengan saham LQ 45. Hasilnya menunjukan 
UNISIA, Vol. XXXII No. 72 Desember 2009

bahwa cost of capitalsaham JII lebih rendah dibanding LQ 45. Cost of Capital yang lebih rendah menunjukan adanya beberapa asumsi yaitu tingkat risiko yang lebih rendah, minimnya asimetri informasi dan biaya keagenan yang lebih rendah sehingga para investor tidak terlalu menuntut tingkat keuntungan.

Hipotesis 1: Praktik manajemen laba pada perusahaan yang terdaftar dalam indeks syari'ah lebih rendah dibandingkan dengan indeks konvensional

\section{Kepemilikan Institusional}

Kepemilikan institusional merupakan saham perusahaan yang dimiliki oleh institusi atau lembaga (perusahaan asuransi, bank, perusahaan investasi dan kepemilikan institusi lain). Kepemilikan institusional memiliki kemampuan untuk mengendalikan pihak manajemen melalui proses monitoring secara efektif sehingga dapat mengurangi manajemen laba. Persentase saham tertentu yang dimiliki oleh institusi dapat mempengaruhi proses penyusunan laporan keuangan yang tidak menutup kemungkinan terdapat akrualisasi sesuai kepentingan pihak manajemen (Gideon, 2005).

McConell dan Servaes (1990), Nesbitt (1994), Smith (1996), Del Guercio dan Hawkins (1999), Hartzell dan Starks (2003) dan Cornertt et al. (2006) menemukan adanya bukti yang menyatakan bahwa tindakan pengawasan yang dilakukan oleh sebuah perusahaan dan pihak investor insitusional dapat membatasi perilaku opportunistic para manajer.

Hipotesis 2: Kepemilikan institusional berpengaruh terhadap praktik manajemen laba

Hipotesis 2a: Kepemilikan institusional perusahaan yang terdaftar dalam indeks syariah berpengaruh terhadap praktik manajemen laba

Hipotesis 2b: Kepemilikan institusional perusahaan yang terdaftar dalam indeks konvensional berpengaruh terhadap praktik manajemen laba

\section{Kepemilikan Manajerial}

Dari sudut pandang teori akuntansi, manajemen laba sangat ditentukan oleh motivasi manajer perusahaan. Motivasi yang berbeda akan menghasilkan besaran manajemen laba yang berbeda, sebab kepemilikan seorang manajer akan ikut menentukan kebijakan dan pengambilan keputusan terhadap metode akuntansi yang diterapkan pada perusahaan yang mereka kelola. Secara umum dapat dikatakan bahwa persentase tertentu kepemilikan saham oleh pihak manajemen cenderung mempengaruhi tindakan manajemen laba (Gideon, 2005).

Warfield et al., (1995) menemukan adanya hubungan negatif antara kepemilikan manajerial dan discretionary accruals sebagai ukuran dari manajemen laba. Hasil yang sama juga diperoleh Jensen dan Meckling (1976), Dhaliwal et al. (1982), Morck et al. (1988) dan Pratana dan Machfoedz (2003).

Shleifer dan Vishny (1986) menyatakan bahwa kepemilikan saham yang besar dari segi nilai ekonomisnya memiliki insentif untuk memonitor. Secara teoritis ketika kepemilikan manajemen rendah, maka insentif terhadap kemungkinan terjadinya perilaku oportunistik manajer akan meningkat.

Hipotesis 3: Kepemilikan manajerial berpengaruh terhadap praktik manajemen laba 
Perbedaan Mekanisme Corporate Governance dan Praktik...; Rina Trisnawati

Hipotesis 3a : Kepemilikan manajerial perusahaan yang terdaftar dalam indeks syariah berpengaruh terhadap praktik manajemen laba

Hipotesis $3 \mathbf{b}$ : Kepemilikan manajerial perusahaan yang terdaftar dalam indeks konvensional berpengaruh terhadap praktik manajemen laba

\section{Proporsi (Komposisi) Dewan Komisaris Independen}

Secara umum dewan komisaris ditugaskan dan diberi tanggung jawab atas pengawasan kualitas informasi yang terkandung dalam laporan keuangan. Selain mensupervisi dan memberi nasihat pada dewan direksi sesuai dengan UU No. 1 tahun 1995, fungsi dewan komisaris yang lain sesuai dengan yang dinyatakan dalam $\mathrm{Na}$ tional Code for Good Corporate Governance 2001 adalah memastikan bahwa perusahaan telah melakukan tanggung jawab sosial dan mempertimbangkan kepentingan berbagai stakeholder perusahaan untuk memonitor efektifitas pelaksanaan good corporate governance.

Penelitian mengenai keberadaan dewan komisaris telah dilakukan diantaranya Peasnell, Pope, dan Young (1998) meneliti efektifitas dewan komisaris dan komisaris independen terhadap manajemen laba yang terjadi di Inggris. Hasil penelitiannya menunjukkan bahwa keberadaan komisaris independen membatasi pihak manajemen untuk melakukan manajemen laba.

Hasil penelitian Dechow, Patricia, Sloan dan Sweeney (1996), Klein (2002), Peasnell, Pope dan Young (2001), Chtourou et al. (2001), Pratana dan Machfoedz (2003), dan Xie et al. (2003) memberikan simpulan bahwa perusahaan yang memiliki proporsi anggota dewan komisaris yang berasal dari luar perusahaan atau outside director dapat mempengaruhi tindakan manajemen laba.

Hipotesis 4:Komposisi dewan komisaris independen berpengaruh terhadap praktik manajemen laba

Hipotesis 4a:Komposisi dewan komisaris independen perusahaan yang terdaftar dalam indeks syariah berpengaruh terhadap praktik manajemen laba

Hipotesis 4b:Komposisi dewan komisaris independen perusahaan yang terdaftar dalam indeks konvensional berpengaruh terhadap praktik manajemen laba

\section{Ukuran Dewan Komisaris}

Terkait manajemen laba, Scott (2006) menyatakan bahwa melakukan manajemen laba dapat dilaksanakan dengan berbagi cara salah satunya menurunkan laba (income decreasing earnings management). Untuk itu hubungan yang terjadi antara ukuran dewan komisaris dan manajemen laba harusnya positif, makin banyak anggota dewan komisaris maka makin banyak manajemen laba yang terjadi. Sebaliknya, Yu (2006), Chtourou, Bedard, dan Courteau (2001) menemukan bahwa ukuran dewan komisaris berpengaruh negatif secara signifikan terhadap manajemen karena sedikitnya dewan komisaris memungkinkan bagi organisasi tersebut untuk didominasi oleh pihak manajemen dalam menjalankan perannya. Namun dalam penelitian mereka hal ini hanya terjadi pada kasus dimana manajemen laba dilakukan dengan penurunan laba (income decreasing), sedang untuk kasus sebaliknya (income increasing earnings management) hasilnya tidak signifikan. 
UNISIA, Vol. XXXII No. 72 Desember 2009

Penelitian Midiastuty dan Machfoedz (2003) menyatakan bahwa ukuran dewan komisaris berpengaruh terhadap indikasi manajemen laba yang dilakukan oleh pihak manajemen. Pengaruh tersebut ditunjukkan dengan tanda positif. Hal tersebut berarti makin besar ukuran dewan komisaris maka makin banyak manajemen laba yang dilakukan oleh perusahaan.

Hipotesis 5 : Ukuran dewan komisaris berpengaruh terhadap praktik manajemen laba

Hipotesis 5a :Ukuran dewan komisaris perusahaan yang terdaftar dalam indeks syariah berpengaruh terhadap praktik manajemen laba

Hipotesis 5b : Ukuran dewan komisaris perusahaan yang terdaftar dalam indeks konvensional berpengaruh terhadap praktik manajemen laba

\section{Keberadaan Komite Audit}

Unsur-unsur (person in charge) dalam corporate governance yang baik menurut Forum for Corporate Governance in Indonesia (FCGI 2003) salah satunya terdiri atas komite audit. Komite audit bertugas memberikan pendapat profesional yang independen kepada dewan komisaris terhadap laporan atau hal-hal yang disampaikan oleh direksi kepada dewan komisaris serta mengidentifikasi hal-hal yang memerlukan perhatian dewan komisris.

Sesuai dengan Kep. 29/PM/2004, komite audit adalah komite yang dibentuk oleh dewan komisaris untuk melakukan tugas pengawasan pengelolaan perusahaan. Keberadaan komite audit sangat penting bagi pengelolaan perusahaan. Selain itu komite audit dianggap sebagai penghubung antara pemegang saham dan dewan komisaris dengan pihak manajemen dalam menangani masalah pengendalian.

Klein (2002) memberikan bukti secara empiris, bahwa perusahaan yang membentuk komite audit independen melaporkan laba dengan kandungan akrual diskresioner yang lebih kecil dibandingkan dengan perusahaan yang tidak membentuk komite audit independen. Kandungan discretionary accruals tersebut berkaitan dengan kualitas laba perusahaan.

Veronica dan Bachtiar (2004) menemukan bahwa komite audit memiliki hubungan yang signifikan dengan akrual kelolaan perusahaan manufaktur di Indonesia khususnya untuk periode 2001-2002, artinya kehadiran komite audit secara efektif menghalangi peningkatan manajemen laba di perusahaan tersebut. Wilopo (2004) menganalis hubungan dewan komisaris independen, komite audit, kinerja perusahaan dan akrual diskresioner. Dari penelitian tersebut dilaporkan bahwa kehadiran komite audit dan dewan komisaris independen mampu mempengaruhi secara negatif praktik manajemen laba di perusahaan.

Hipotesis 6:Keberadaan komite audit independen berpengaruh terhadap praktik manajemen laba

Hipotesis 6a:Keberadaan komite audit independen yang terdaftar dalam indeks syariah berpengaruh terhadap praktik manajemen laba

Hipotesis 6b:Keberadaan komite audit independen yang terdaftar dalam indeks konvensional berpengaruh terhadap praktik manajemen laba 
Perbedaan Mekanisme Corporate Governance dan Praktik...; Rina Trisnawati

\section{Metode Penelitian}

\section{Populasi dan Sampel}

Populasi dalam penelitian ini adalah seluruh perusahaan yang terdaftar di Bursa Efek Indonesia. Teknik pengambilan sampel dilakukan secara purposive sampling dengan tujuan untuk mendapatkan sampel yang representatif.

\section{Variabel Penelitian}

Earnings managementsebagai variabel dependen diproksi dengan discretionary accruals dan dihitung dengan The Modified Jones Model:

$$
\begin{aligned}
& \mathrm{TACC}_{\text {it }}=\mathrm{EBXT}_{\text {it }}-\mathrm{OCF}_{\text {it }} \\
& \operatorname{TACC}_{\mathrm{it}} / \mathrm{TA}_{\mathrm{i}, \mathrm{t}-1}=\mathrm{a}_{1}\left(1 / \mathrm{TA}_{\mathrm{it-1}-1}\right)+\mathrm{a}_{2}\left(\left({ }^{\mathrm{N}} \mathrm{REV}_{\mathrm{it}}{ }^{-}\right.\right. \\
& \text {"REC } \mathrm{it} / \mathrm{TA} \mathrm{A}_{\mathrm{i}, \mathrm{t}-1} \text { ) } \\
& \text { + á } 3\left(\mathrm{PPE}_{\mathrm{i} t} / \mathrm{TA}_{\mathrm{i}, \mathrm{t}-1}\right) \text {. }
\end{aligned}
$$

Dari persamaan regresi diatas, NDACC (non discretionary) dapat dihitung dengan memasukkan kembali koefisien -koefisien alpha (á) yaitu sebagai berikut:

$$
\begin{aligned}
& \operatorname{NDACC}_{i t}=a_{1}\left(1 / T A_{i, t-1}\right)+a_{2}\left(\text { (“ } \operatorname{REV}_{\mathrm{it}}\right. \text {-" } \\
& \left.\left.\mathrm{REC}_{\mathrm{it}}\right) / \mathrm{TA} \mathrm{A}_{\mathrm{i}, \mathrm{-1}}\right) \\
& +a_{3}\left(P P E_{i t} / T_{i, t-1}\right)
\end{aligned}
$$

Selanjutnya dapat dihitung nilai discretionary accruals sebagai berikut:

$$
\text { DACC }_{i t}=\left(\text { TACC }_{i t} / T_{i, t-1}\right)-\text { NDACC }_{i t}
$$

Variabel Independen dalam penelitian ini adalah corporate governance yang pengukurannya dapat diringkas sebagai berikut ini

Kepemilikan Institusional (INSTOWN) : jumlah persentase hak suara yang dimiliki oleh institusi (Beiner et al, 2003)

Kepemilikan Manajerial (MGROWN) dummy untuk menunjukkan adanya kepemilikan manajerial (Mahadwartha, 2002)
Proporsi Dewan Komisaris Independen (BOARDINDP). persentase jumlah dewan komisaris independen terhadap jumlah total komisaris yang ada dalam susunan dewan komisaris perusahaan

Ukuran Dewan Komisaris (BOARDSIZE) : jumlah anggota dewan komisaris perusahaan (Beiner et al, 2003).

Keberadaan Komite Audit (AUDCOM) : Dummy variabel

\section{Teknik Analisis Data}

Sebelum dilakukan pengujian hipotesis, maka data yang diperoleh dalam penelitian ini akan diuji terlebih dahulu untuk memenuhi asumsi dasar yang neliputi pengujian normalitas data, heteroskedastisitas, multikolinearitas, dan uji Chow untuk menganalisis apakah pada dua perusahaan yang berbeda terdapat stabilitas struktural pada persamaan regresi yang dianalisis,

Pengujian hipotesis pertama $(\mathrm{H} 1)$, dilakukan dengan menggunakan independent samples t-test. Pengujian hipotesis berikutnya ( $\mathrm{H} 2$ sampai dengan $\mathrm{H} 6$ ) digunakan alat analisis regresi berganda. Model persamaan regresi tersebut sebagai berikut :

DACC =á $+\hat{a}_{1}$ INSTOWN $+\hat{a}_{2}$

MGROWN $+\hat{a}_{3}$ BOARDINDP $+\hat{a}_{4}$ BOARDSIZE $+\hat{a}_{5}$ AUDCOM + e

Dari model diatas, dilakukan analisis secara terperinci untuk menguji faktor apa yang menyebabkan perbedaan praktik manajemen laba pada kedua kelompok sampel dengan model sebagai berikut ini : 
UNISIA, Vol. XXXII No. 72 Desember 2009

\section{a. Regresi untuk indeks syariah}

DACC $_{1}=\mathrm{á}+\hat{a}_{1}$ INSTOWN + + $\hat{a}_{2} M G R O W N+\hat{a}_{3} B O A R D I N D P+$ $\hat{a}_{4} B O A R D S I Z E+\hat{a}_{5} A U D C O M+e$

\section{b. Regresi untuk indeks konvensional}

DACC $_{2}=$ á $+\hat{a}_{1}$ INSTOWN $+\hat{a}_{2}$ MGROWN $+\hat{a}_{3}$ BOARDINDP + $\hat{a}_{4}$ BOARDSIZE + $\hat{a}_{5} A U D C O M+e$

\section{Analisis Data dan Pembahasan}

\section{Hasil Pengumpulan Data}

Data penelitian berasal dari laporan keuangan auditan perusahaan yang terdaftar dalam indeks syariah (JII) dan indeks konvensional (LQ-45) di PT. Bursa Efek Indonesia (BEI) pada periode 2004-2007. Berdasarkan kriteria pengambilan sampel, maka diperoleh sampel penelitian yang diperinci sebagai berikut:

\section{Pengujian Hipotesis}

\section{Pengujian Hipotesis 1}

Uji independent sample t-test digunakan untuk menguji hipotesis pertama. Hasil perhitungan statistik menunjukkan bahwa rata-rata akrual kelolaan perusahaan dalam indeks konvensional (0.474) dan nilai ratarata akrual kelolaan perusahaan dalam indeks syariah (0.276). Hasil uji statistik juga menunjukkan bahwa terdapat perbedaan signifikan praktik manajemen laba pada perusahaan dalam indeks syariah dan indeks konvensional (prob.value=0.016). Hal ini berarti praktik manajemen laba yang cenderung meningkatkan laba lebih banyak dilakukan pada perusahaan dalam indeks konvensional dibandingkan perusahaan dalam indeks syariah.

Hasil analisis ini juga menunjukkan bahwa pada periode 2004-2007 perusahaan yang terdaftar dalam indeks syariah dan indeks konvensional di Indonesia mela-

Tabel 1 Kriteria Pengambilan Sampel

\begin{tabular}{lc}
\hline Sampel Perusahaan Syariah (JII) & 120 \\
Jumlah perusahaan yang terdaftar di JII selama periode 2004-2007 & $(22)$ \\
Jumlah perusahaan yang data tidak lengkap & $\frac{(9)}{\mathbf{8 9}}$ \\
Outlier & Jumlah perusahaan yang menjadi sampel JII
\end{tabular}

Sampel Perusahaan Konvensional (LQ-45)

Jumlah perusahaan yang terdaftar di LQ-45 selama periode 20042007

Jumlah perusahaan yang terdaftar di LQ-45

Jumlah perusahaan industri perbankan, asuransi dan keuangan lain

Jumlah perusahaan yang menjadi sampel LQ-45

Sumber: www.idx.co.id 
Perbedaan Mekanisme Corporate Governance dan Praktik...; Rina Trisnawati

kukan tindak manajemen laba dengan pola memaksimalkan labanya. Hasil ini mendukung penelitian yang dilakukan oleh DeFond dan Jiambalvo (1994); Sweeney (1994); Peltier-Rivest (1999); Jaggi dan Lee (2001); Rosner (2003); Djakman (2003); Syam (2004); Andriyani (2004); dan Kusumawati dan Sasongko (2005) yang memberikan bukti empiris mengenai pola manajemen laba dalam bentuk meningkatkan laba yang dilaporkan. terhadap manajemen laba (hipotesis 3 dan $3 a$ tidak didukung). Pengujian hipotesis $3 \mathrm{~b}$ menunjukkan bahwa Ha didukung, (prob value $(0,037)<0.05)$ dengan demikian kepemilikan manajerial perusahaan yang terdaftar dalam indeks konvensional berpengaruh signifikan terhadap praktik manajemen laba.

Hasil penelitian ini mendukung hasil penelitian yang dilakukan Jensen dan

Tabel 2 Hasil Analisis Regresi

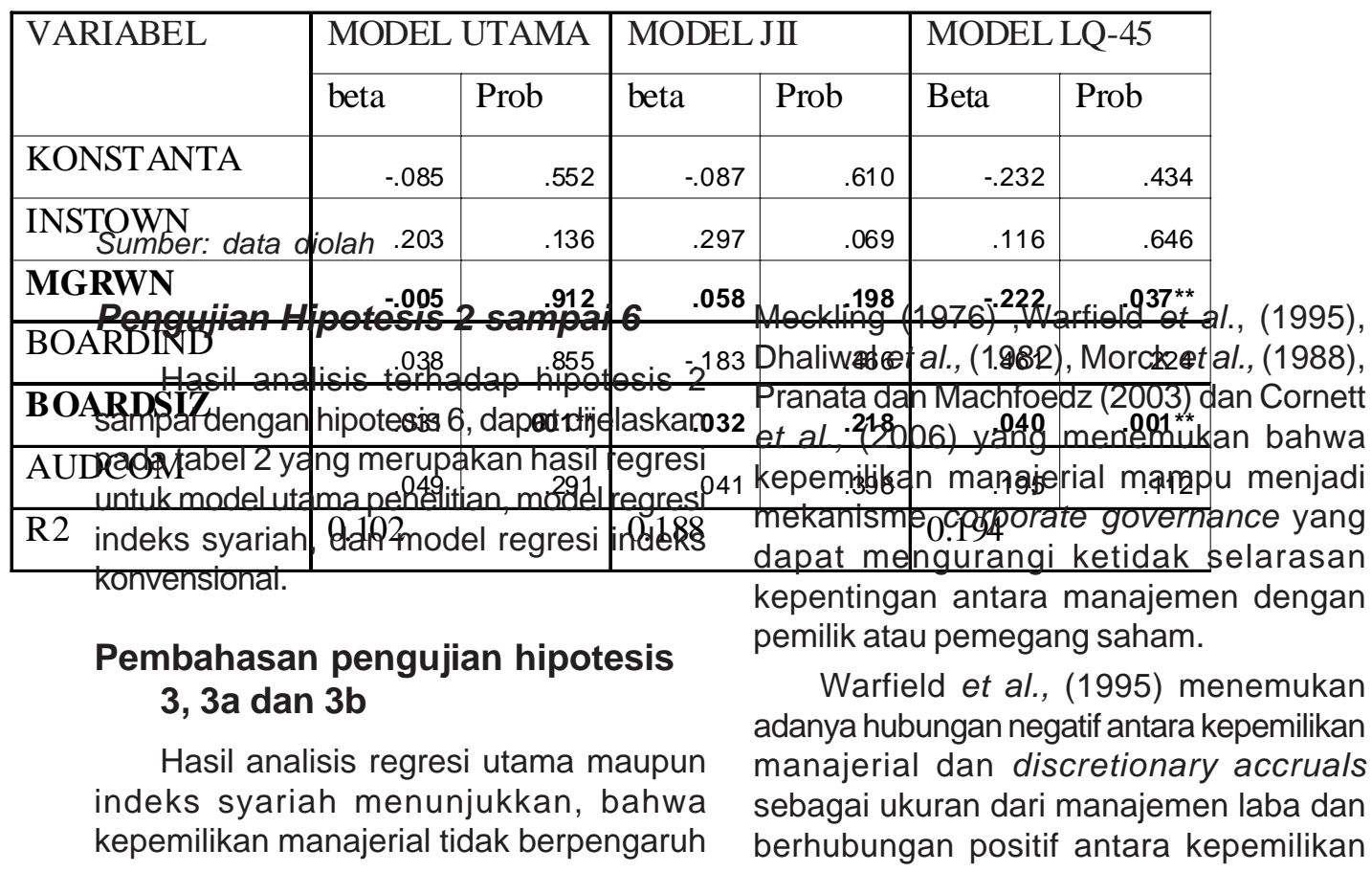


UNISIA, Vol. XXXII No. 72 Desember 2009

manajerial dengan kandungan informasi dalam laba. Hasil yang sama juga diperoleh Jensen dan Meckling (1976), Dhaliwal et al. (1982), Morck et al. (1988) dan Pratana dan Mas'ud (2003). Shleifer dan Vishny (1986) menyatakan bahwa kepemilikan saham yang besar dari segi nilai ekonomisnya memiliki insentif untuk memonitor. Secara teoritis ketika kepemilikan manajemen tinggi, maka insentif terhadap kemungkinan terjadinya perilaku oportunistik manajer akan berkurang.

\section{Pembahasan Hipotesis 5, 5a dan 5b}

Berdasarkan hasil regresi utama dapat dijelaskan bahwa ukuran dewan komisaris berpengaruh positif terhadap manajemen laba (hipotesis 5 didukung). Artinya makin besar ukuran dewan komisaris dalam perusahaan makin tinggi praktik manajemen laba. Hal ini dapat dijelaskan bahwa penempatan atau penambahan anggota dewan komisaris dimungkinkan hanya sekedar memenuhi ketentuan formal, sementara pemegang saham mayoritas (pengendali/founders) masih memegang peranan penting sehingga kinerja dewan tidak meningkat bahkan turun (Gideon, 2005). Banyaknya dewan komisaris bukanlah menjadi faktor penentu utama dari efektivitas pengawasan terhadap manajemen perusahaan. Akan tetapi efektivitas mekanisme pengendalian tergantung pada nilai, norma dan kepercayaan yang diterima dalam suatu organisasi (Jennings 2004a; 2004b; 2005a; Oliver, 2004) serta peran dewan komisaris dalam aktivitas pengendalian (monitoring) terhadap manajemen (Cohen, et al. 2004; Jennings 2005b).

Sylvia dan Siddharta (2005) juga menyatakan bahwa pengangkatan dewan komisaris independen oleh perusahaan mungkin hanya dilakukan untuk pemenuhan regulasi saja tapi tidak dimaksudkan untuk menegakkan Good Corporate Governance (GCG) di dalam perusahaan. Kondisi ini juga ditegaskan dari hasil survai Asian Development Bank dalam Gidoen (2005) yang menyatakan, bahwa kuatnya kendali pendiri perusahaan dan kepemilikan saham mayoritas menjadikan dewan komisaris tidak independen. Fungsi pengawasan yang seharusnya menjadi tanggungjawab anggota dewan menjadi tidak efektif.

Hasil ini didukung dengan regresi konvensional yang menunjukkan bahwa ukuran dewan komisaris berpengaruh positif signifikan terhadap praktik manajemen laba (Hipotesis 5b didukung), sedangkan hipotesis 5 a tidak didukung. Hal ini berarti banyaknya dewan komisaris independen perusahaan indeks syariah tidak mempengaruhi manajemen laba. Hasil ini memberikan penjelasan bahwa ukuran dewan komisaris perusahaan yang terdaftar dalam indeks konvensional memiliki pengaruh yang lebih besar terhadap praktik manajemen laba dibandingkan ukuran dewan komisaris perusahaan yang terdaftar dalam indeks syariah. Pengaruh yang lebih besar ini dapat dilihat dari koefisien beta yang menunjukkan nilai positif dan signifikan.

Penelitian ini memberi hasil yang berlawanan dengan Xie, Davidson, Dadalt (2003), Yu (2006), Zhou dan Chen (2004), dan Chtourou, Bedard, dan Courteau (2001) yang menunjukkan bahwa ukuran dewan komisaris yang lebih besar mampu mengurangi manajemen laba dalam perusahaan, yang ditunjukkan dengan koefisien negatif yang signifikan.

\section{Penutup}

\section{Kesimpulan}

1) Terdapat perbedaan praktik manajemen laba pada perusahaan dalam indeks syariah dan indeks konvensional $(\mathrm{H} 1$ 
Perbedaan Mekanisme Corporate Governance dan Praktik...; Rina Trisnawati

didukung) dan rata-rata akrual kelolaan perusahaan dalam indeks konvensional (0.402756000) lebih tinggi dibandingkan indeks syariah (0.233788427).

2) Hasil pengujian hipotesis 2 sampai 6 menunjukkan bahwa hipotesis $3 \mathrm{~b}$ didukung (kepemilikan manajerial berpengaruh negatif signifikan terhadap praktik manajemen laba pada indeks konvensional), sedangkan hipotesis 3 dan 3a tidak didukung. Hasil analisis juga menunjukkan, bahwa untuk hipotesis 5 didukung (ukuran dewan komisaris berpengaruh positif signifikan terhadap praktik manajemen laba). Untuk model regresi indeks syariah menunjukkan hipotesis $5 \mathrm{a}$ tidak didukung, tetapi untuk indeks konvensional (hipotesis 5b) didukung.

3) Secara keseluruhan dapat disimpulkan bahwa mekanisme corporate governance belum seluruhnya efektif mengurangi praktik manajemen laba pada perusahaan yang terdaftar di indeks konvensional maupun indeks syariah di Indonesia.

Implikasi

1) Nilai adjusted $R^{2}$ relatif kecil, maka untuk penelitian selanjutnya perlu meneliti variabel lain yang mungkin mempengaruhi manajemen laba, misalnya peningkatan nilai saham (Dechow 1994, Teoh et al. 1998, dan Gumanti 2000).

2) Prespektif manajemen laba yang digunakan dalam penelitian ini adalah prespektif oportunistis. Untuk penelitian selanjutnya, manajemen laba perlu ditinjau dari prespektif yang lain, misalnya prespektif efisiensi dan perspektif positif.

3) Variabel mekanisme corporate governance diwakilkan oleh kepemilikan institusional, kepemilikan manajerial, komposisi dewan komisaris, ukuran dewan komisaris, dan keberadaan komite audit. Kelima variabel ini kurang dapat mengukur secara komprehensif praktik corporate governance dalam perusahaan, sehingga perlu adanya angka indeks yang mencerminkan praktik corporate governance secara lebih tepat. Selain itu karakteristik komisaris independen dan komite audit secara spesifik tidak disertakan.

4) Model untuk menghitung discretionary accrual dalam penelitian ini adalah model Jones (1991) yang dimodifikasi. Perlu proksi lain dari manajemen laba misalnya cross-sectional abnormal accrual model (Peasnell et al., 1998), absolute discretionary accrual (Rajgofal et al., 1999) dan prlu pengujian model yang paling sesuai untuk kondisi di Indonesia.

\section{Daftar Pustaka}

Boediono, Gideon SB., 2005. Kualitas Laba: Studi Pengaruh Mekanisme Corporate Governance dan Dampak Manajemen Laba dengan Meng-gunakan Analisis Jalur. Artikel yang Dipresentasikan pada Simposium Nasional Akuntansi 8 Solo tanggal 15 16 September 2005.

Carcello, Joseph V., Carl W. Hollingsworth, April Klein, and Terry L. Neal. 2006. Audit Committee Financial Expertise, Competing Corporate Governance Mechanisms, and Earnings Management. Available online at www.ssrn. com

Chtourou, Sonda Marrakchi, Jean Bedard and Lucie Courteau. 2001. Corporate Governance and Earnings Manage- 
UNISIA, Vol. XXXII No. 72 Desember 2009

ment. Available online at www.ssrn. com

Cornett M. M, J. Marcuss, Saunders dan Tehranian H. (2006). Earnings Management, Corporate Governance, and True Financial Performance. http:// papers.ssrn. com/

Djakman, Chaerul D. 2003. Manajemen Laba dan Pengaruh Kebijakan Multi Papan Bursa Efek Jakarta. Makalah disampaikan dalam Simposium Nasional Akuntansi VI di Surabaya, 16-17 Oktober.

Eisenhardt, Kathleem. M. 1989. Agency Theory: An Assesment and Review. Academy of Management Review, 14, p. $57-74$

Fatwa Dewan Syari'ah Nasional No: 40/ DSN-MUI/X/2003 Tentang Pasar Modal dan Pedoman Umum Penerapan Prinsip Syari'ah di Bidang Pasar Modal

Forum for Corporate Governance in Indonesia. 2003. Indonesian Company Law. Available on-line at www.fcgi.org.id

Gumanti, T.A. (2000). Earnings Management Dalam Penawaran Saham Perdana di Bursa Efek Jakarta. Makalah Simposium Nasional Akuntansi III. 124-148.

Hanafi, Syafiq. M. 2007. Ethical Screening Pada Jakarta Islamic Index (JII): Antara Strategi Bisnis Dan Bisnis Strategi?

Hanafi, Syafiq. M. 2006. Corporate Governance: Kajian Empiris Cost of Capital Jakarta Islamic Index (JII) sebagai
Ethical Investment. As-Syir'ah, Vol. 40 No. 1 Tahun 2006

Herawaty, Vinola. Peran Praktek Corporate Governance Sebagai Moderating Variable Dari Pengaruh Earnings Management Terhadap Nilai Perusahaan. Makalah disampaikan dalam Simposium Nasional Akuntansi XI di Makassar, 26-28 Juli.

Jensen, Michael C. dan W.H. Meckling. (1976). Theory of The Firm: Managerial Behavior, Agency Cost and Ownership Structure. Journal of Financial Economics 3. hal. 305-360.

Komite Nasional Kebijakan Governance, (2004). Pedoman Tentang Komisaris Independen. http://www.governanceindonesia.or.id/main.htm.

Kusumawati, Astri Arfani Nur dan Noer Sasongko. 2005. Analisis Perbedaan Pengaturan Laba (Earnings Management) pada Kondisi Laba dan Rugi pada Perusahaan Manufaktur di Indonesia. Jurnal Akuntansi dan Keuangan, Vol. 4, No. 1. hal.1-20.

Midiastuty, Pratana P., dan Mas'ud Machfoedz. 2003. Analisis Hubungan Mekanisme Corporate Governance dan Indikasi Manajemen Laba. Artikel yang Dipresentasikan pada Simposium Nasional Akuntansi 6 Surabaya tanggal 16-17 Oktober 2003

Nasution, Marihot dan Doddy Setiawan. 2007. Pengaruh Corporate Governance Terhadap Manajemen Laba di Industri Perbankan Indonesia. Makalah disampaikan dalam Simposium Nasional Akuntansi X di Makassar, 26-28 Juli. 
Perbedaan Mekanisme Corporate Governance dan Praktik...; Rina Trisnawati

Peasnell, K.V, P.F. Pope. dan S.Young. (2001). Board Monitoring and Earnings Management: Do Outside Directors Influence Abnormal Accruals. Accounting and Business Research, Vol. 30. hal.41-63.

Pratana dan Mas'ud Machfoed (2003). Analisa Hubungan Mekanisme Corporate Governanace dan Indikasi Manajemen Laba. Simposium Nasional Akuntansi VI. IAI, 2003.

Rahmawati, Yacop Suparno, dan Nurul Qomariyah. 2006. Pengaruh Asimetri Informasi terhadap Praktik Manajemen Laba pada Perusahaan Perbankan Publik yang Terdaftar di Bursa Efek Jakarta. Artikel yang Dipresentasikan pada Simposium Nasional Akuntansi 9 Padang tanggal 23-26 Agustus 2006

Rajgopal, S., M. Venkatachalam, and J. Jiambalvo. 1999. Is Institutional Ownership Associated with Earnings Management and the Extent to which Stock Prices Reflect Future Earnings?. Working Paper, http:// papers.ssrn. com/sol3/papers.cfm? abstract_id=163433, March, pp 1-30.

Scott, William R. (2006). Financial Acconting theory. $4^{\text {th }}$ Edition. Canada Inc : Pearson Education.

Shah, Syed Zulfiqar Ali., Safdar Ali Butt dan Arshad Hasan. 2009. Corporate Governance and Earnings Management an Empirical Evidence Form Pakistani Listed Companies. European Journal of Scientific Research

Ujiyantho, Muh. Arief, dan B. A. Pramuka, 2007. Mekanisme Corporate Gover- nance, Manajemen Laba dan Kinerja Keuangan: Studi Pada Perusahaan Go Publik Sektor Manufaktur. Kumpulan Makalah, Simposium Nasional Akuntansi (SNA) X, Makassar, 26-27 Juli, h 1-26.

Veronica, Sylvia, dan Siddharta Utama. 2005. Pengaruh Struktur Kepemilikan, Ukuran Perusahaan, dan Praktek Corporate Governance terhadap Pengelolaan Laba (Earnings Management). Artikel yang Dipre-sentasikan pada Simposium Nasi-onal Akuntansi 8 Solo tanggal 15 - 16 September 2005

Veronica, Sylvia dan Yanivi S Bachtiar. 2004. Good Corporate Governance Information Asymetry and Earnings Management. Artikel yang Dipresentasikan pada Simposium Nasional Akuntansi 7 Denpasar tanggal 2 -3 Desember 2004

Warfield, T., J Wild, and K. Wild. (1995). Managerial Ownership, Accounting Choices, and Informativeness of Earnings. Journal of Accounting and Economics, Vol.20. No.1. July, p.6191.

Watts, Ross L and Jerold L. Zimmerman. 1978. Towards a Positive Theory of The Determination of Accounting Standards. The Accounting Review. Vol LIII. No.1

Wedari, Linda Kusumaning. 2004. Analisis Pengaruh Proporsi Dewan Komisaris dan Keberadaan Komite Audit terhadap Aktivitas Manajamen Laba. Artikel yang Dipresentasikan pada Simposium Nasional Akuntansi 7 
UNISIA, Vol. XXXII No. 72 Desember 2009

Denpasar tanggal 2 -3 Desember 2004

Wilopo. 2004. The Analysis of Relationship of Independent Board of Directors, Audit Committee, Corporate Perfor- mance, and Discretionary Accruals. Ventura Volume 7 No. 1 April: 73-83

Xu, Xiaonian., and Yan Wang. 1997. Ownership Structure, Corporate Governance and Corporate Performance : The Case of Chinese Stock Companies. 